\title{
Apoptotic Death of $\beta$ Cells after Optic Nerve Transection in Adult Cats
}

\author{
Takuji Kurimoto, ${ }^{1,2}$ Tomomitsu Miyoshi, ${ }^{1}$ Akira Suzuki, ${ }^{1}$ Toru Yakura, ${ }^{1}$ Masami Watanabe, ${ }^{3}$ Osamu Mimura, ${ }^{2}$ and \\ Yutaka Fukuda ${ }^{1}$ \\ ${ }^{1}$ Department of Physiology and Biosignaling, Graduate School of Medicine, Osaka University, Suita, Osaka 565-0871, Japan, ${ }^{2}$ Department of \\ Ophthalmology, Hyogo College of Medicine, Nishinomiya, Hyogo 663-8501, Japan, and ${ }^{3}$ Department of Physiology, Institute for Developmental Research, \\ Kasugai, Aichi 480-0392, Japan
}

We have revealed previously that the survival rate of $\beta$ cells of cat retinal ganglion cells (RGCs) rapidly decreased to $29 \%$ on day 7 after optic nerve transection, whereas that of $\alpha$ cells slowly decreased to $64 \%$ on day 14 (Watanabe et al., 2001). The reason that $\beta$ cells die more rapidly than $\alpha$ cells was not clear. In the present study, we tested the possibility that the rapid death of $\beta$ cells is attributable to apoptosis, as shown for some axotomized RGCs in rats. The following results were obtained. First, the proportion of pyknotic cells in Nissl-stained cat retinas started to increase sharply starting on day 4 and reached a peak on day 6 after optic nerve transection. The time course of occurrence of pyknotic cells corresponded well with that of the rapid death of axotomized $\beta$ cells. Secondly, the proportion of pyknotic cells was the highest in the area centralis (AC), in which $\beta$ cells are densely distributed. The preferential death of axotomized RGCs in the AC was also confirmed by terminal deoxynucleotidyl transferase-mediated biotinylated UTP nick end labeling staining in cross sections. Thirdly, after the intravitreal injection of caspase 3 inhibitor (z-DEVD-cmk) the survival of axotomized $\beta$ cells on day 7 was significantly enhanced, whereas no such survival-promoting effect was obtained in axotomized $\alpha$ cells. Taken together, these results suggest that the rapid death of axotomized $\beta$ cells is attributable mainly to apoptosis, which is mediated by caspase 3 .

Key words: adult cat; retinal ganglion cells; $\beta$ cells; optic nerve transection; apoptosis; caspase 3 inhibitor

\section{Introduction}

After the transplantation of a piece of peripheral nerve, axotomized retinal ganglion cells (RGCs) of adult mammals can regenerate their axons (So and Aguayo, 1985, Vidal-Sanz et al., 1987). We have shown previously in adult cats that RGCs with regenerated axons through the peripheral nerve graft preserve their dendritic morphology (Watanabe et al., 1993) and receptive field properties even 2 months after optic nerve transection (Miyoshi et al., 1999). However, besides the paucity of RGCs that regenerate their axons, we noted that the regeneration capacity was quite different among the cat RGC types: for example, of the two major cell types, $\beta$ cells have much less regeneration capacity than $\alpha$ cells (Watanabe et al., 1993). The survival rate at 2 months after optic nerve transection was also much less in $\beta$ cells than in $\alpha$ cells (Watanabe et al., 1995), consistent with previous work done on cat RGCs with transected or crushed optic nerve (Holländer et al., 1984; Cottee et al., 1991; Silveira et al., 1994). Thus, it is most

\footnotetext{
Received Sept. 25, 2002; revised March 3, 2003; accepted March 5, 2003.

This work was supported by the Strategic Promotion System for Brain Science by Special Coordination Funds for Promoting Science and Technology [Ministry of Education, Culture, Sports, Science and Technology of Japan (MEXT)], Grants-in-Aid for Scientific Research 13771023, 11694274, 12671733 from MEXT; health sciences research grants from the Ministry of Health, Labour and Welfare of Japan, the Osaka Eye Bank Research Fund, and the Marine and Fire Insurance Association of Japan.

Correspondence should be addressed to Dr. Tomomitsu Miyoshi, Department of Physiology and Biosignaling, Graduate School of Medicine, Osaka University, A5, 2-2 Yamadaoka, Suita City, Osaka 565-0871, Japan. E-mail: tmiyoshi@phys2.med.osaka-u.ac.jp.

Copyright $\odot 2003$ Society for Neuroscience $\quad$ 0270-6474/03/234023-06\$15.00/0
}

probable that the weak regeneration ability of $\beta$ cells can be ascribed to their poor survival ability after optic nerve transection.

The survival time course was clearly different between $\alpha$ and $\beta$ cells within 2 weeks after optic nerve transection (Watanabe et al., 2001). Axotomized $\beta$ cells specifically suffer from a rapid death between day 3 and 7 after optic nerve transection, whereas $\alpha$ cells die more gradually, and 64\% survived $14 \mathrm{~d}$ after axotomy (Watanabe et al., 2001). In support of this study, Silveira et al. (1994) observed with silver staining that axotomized $\beta$ cells degenerated faster than other cell types of cat RGCs from days 3.5 to 7 after surgery. They also noted that some degenerated cells revealed a pyknotic nucleus on day 3.5 after axotomy in Nissl-stained retina, although the relationship between specific RGC types and the pattern of cell death was not demonstrated. Why do $\beta$ cells of the cat RGCs die so quickly after optic nerve transection?

From recent works done mostly on rats, it is now well established that some RGCs die by apoptosis after the optic nerve injury (Berkelaar et al., 1994; Garcia-Valenzuela et al., 1994; Isenmann et al., 1997). After the optic nerve crush in adult rats, the number of RGCs stained with the terminal deoxynucleotidyl transferase-mediated biotinylated UTP nick end labeling (TUNEL) method, which can detect DNA fragmentation during apoptosis, peaks 6 or $7 \mathrm{~d}$ after the surgery (Garcia-Valenzuela et al., 1994; Isenmann et al., 1997). Moreover, by the intravitreal application of the inhibitor of caspase 3, which is an essential executor of apoptotic cell death, axotomized RGCs can be rescued in adult rats (Kermer et al., 1998; Chaudhary et al., 1999). 
Given such ample evidence for apoptotic cell death among axotomized rat retinas, there arises a possibility that the rapid death of $\beta$ cells after axotomy is attributable to apoptosis. In the present study, we first examined in Nissl-stained cat retinas after optic nerve transection whether pyknotic cells preferentially appear in the central retina, where $\beta$ cells are densely distributed (Fukuda and Stone, 1974; Hughes, 1981). Secondly, we examined whether the time course of the occurrence of pyknotic cells corresponds to the sharp death period of $\beta$ cells, i.e., 3-7 $\mathrm{d}$ after optic nerve transection (Watanabe et al., 2001). Thirdly, after the celltype identification with intracellular injections of Lucifer yellow into each surviving RGC, we examined whether the death of $\beta$ cells can be specifically rescued by the intravitreal injection of caspase 3 inhibitor. The results of these series of experiments all support the hypothesis that the retrograde cell death of $\beta$ cells after optic nerve transection is attributable to apoptosis but not that of $\alpha$ cells in adult cats.

\section{Materials and Methods}

General procedure. Thirty-eight adult cats weighing $2.5-3.5 \mathrm{~kg}$ were used. All experimental procedures were performed in accordance with the institutional guidelines for laboratory animal care and treatment and with the standards for care and use of laboratory animals of National Institutes of Health guidelines. The cats were initially anesthetized with ketamine hydrochloride $(50 \mathrm{mg}$, i.m.) and then maintained with gas anesthesia of oxygen $1.5 \mathrm{l} / \mathrm{min}$, nitrous oxide $1.5 \mathrm{l} / \mathrm{min}$, and $1-2 \%$ halothane during the surgery. After enucleation of the eyes, the cats were killed with an overdose of sodium pentobarbital injected intravenously.

Optic nerve transection. Surgical procedures for optic nerve transection were described previously (Watanabe et al., 1995). The bones over the frontal sinus and the orbit were removed and the left optic nerve was exposed. To avoid injuring the central retinal artery, the optic nerve sheath was cut longitudinally with microscissors. Then the optic nerve was pulled up from the sheath with an L-shaped hook and was cut at 3-4 $\mathrm{mm}$ behind the eyeball. Retinal vessels were verified to be intact with a funduscope. The skin over the orbit was sutured with 3-0 nylon, and penicillin $(20,000 \mathrm{U})$ was administered subcutaneously at the end of the surgery.

Evaluation of relative proportions of pyknotic cell in Nissl-stained retinas. Three to $14 \mathrm{~d}$ after the optic nerve transection, the operated eye was enucleated, immediately hemisectioned, and fixed with $4 \%$ paraformaldehyde in $0.1 \mathrm{~m}$ phosphate buffer. Two hours after fixation, the retinas were dissected and flat-mounted on gelatin-coated glass slides. Nissl staining was performed with $0.1 \%$ cresyl violet (Chroma-Gesellschaft, Köngen, Germany) and coverslipped.

We counted pyknotic cells at three different sites in each Nissl-stained retina. Using a stage controller (Microscanner, MJ Mechanics, Fujieda, Japan), we accurately located the three examined sites: the area centralis (AC; sample area, $0.0625 \mathrm{~mm}^{2}$ ), the temporal $3 \mathrm{~mm}$ from the AC on a horizontal line $\left(0.25 \mathrm{~mm}^{2}\right)$, and the midpoint between the optic disk and AC $\left(0.25 \mathrm{~mm}^{2}\right)$ (see Fig. $2 \mathrm{~A}$ ). To identify Nissl-stained cells as neurons in the ganglion cell layer (GCL), we used the criteria described previously about the size and shape of somata, nuclei, and cytoplasm and the distribution of the Nissl granules (Hughes, 1975). With these criteria, displaced amacrines were included in counted neurons. The densities of Nissl-stained neurons in each of the three examined retinal sites of intact retina corresponded well with those reported previously (Hughes, 1981). To identify pyknotic cells we adopted the criteria described previously: a darkly stained and condensed nucleus (Wyllie et al., 1980; Perry et al., 1983). Then we calculated the proportion of pyknotic cells $\left(P_{\mathrm{pyk}}\right)$ in the axotomized retina using the following formula: $P_{\text {pyk }}(\%)=N_{\text {pyk }} /\left(N_{\text {pyk }}+\right.$ $N_{\text {neu }}$ ) $\times 100$, where $N_{\text {pyk }}$ is the number of pyknotic cells and $N_{\text {neu }}$ is the number of Nissl-stained neurons in the axotomized retina.

TUNEL staining. To detect DNA fragmentation, the TUNEL method was applied to axotomized cat retina with an Apoptosis in situ Detection Kit (Wako, Osaka, Japan). Six days after optic nerve transection, enucleated eyes were hemisectioned, fixed with $4 \%$ paraformaldehyde for $48 \mathrm{hr}$ at $4^{\circ} \mathrm{C}$, and then transferred to $30 \%$ sucrose. Soaked eyecups were partially cut to make two differential pieces. One piece included the AC of the central retina; the other piece included the peripheral retina, which was $\sim 5 \mathrm{~mm}$ temporal from the AC. The size of each piece was $3 \times 3 \mathrm{~mm}$. The pieces were frozen, vertically sectioned at $16 \mu \mathrm{m}$ thick, and then recovered on 3-aminopropyltriethoxysilane-coated slides. According to the manufacturer's instructions, DNA fragmentation was visualized by diaminobenzidine and observed under a differential interference contrast microscope.

Retrograde labeling of RGCs. Retrograde labeling of RGCs was done as described previously (Watanabe et al., 2001). Briefly, 1,1'-dioctadecyl$3,3,3^{\prime}, 3^{\prime}$-tetramethylindocarbocyanine perchlorate (DiI; Molecular Probes, Eugene, OR) was suspended in saline with dimethylsulfoxide (DMSO) and $0.1 \%$ Triton X-100 at a concentration of $5 \mathrm{mg} / \mathrm{ml}$. Using a $10 \mu \mathrm{l}$ Hamilton syringe with electrical insulation except for its tip, the DiI suspension was injected into the bilateral lateral geniculate nuclei and optic tracts with their identification by stereotaxic coordinates (anterior, $2.0-9.0 \mathrm{~mm}$; lateral, 8.5 or $9.0 \mathrm{~mm}$ ) and recordings of field responses from the syringe tip. The suspension $(50-60 \mu \mathrm{l})$ was injected to each side.

Application of caspase 3 inhibitor. An irreversible inhibitor of CPP32like caspases, benzyloxycarbonyl-Asp-Glu-Val-Asp-chloromethylketone (zDEVD-cmk; Bachem AG, Bubendorf, Switzerland) was used to make the final vitreous concentration of z-DEVD-cmk higher than those used in several in vitro studies (Bourteele et al., 1998; Schäfer et al., 1998; Macho et al., 1999). z-DEVD-cmk $500 \mu \mathrm{g}$ was dissolved in $50 \mu \mathrm{l}$ of the solution containing $10 \%$ DMSO in PBS. Immediately after the optic nerve transection, a hole was made on the sclera with a 26 gauge needle, then the solution of z-DEVD-cmk $50 \mu$ l or vehicle $50 \mu \mathrm{l}$ (10\% DMSO in PBS) was applied into the vitreous body through the hole with a Hamilton syringe. Care was taken not to injure the lens. Assuming an approximate volume of the vitreous to be $3.7 \mathrm{ml}$ (Vakkur and Bishop, 1963), the estimated concentration of z-DEVD-cmk injected was over $120 \mu \mathrm{m}$.

Measurement of densities of DiI-labeled RGCs in the AC. DiI-labeled RGCs were observed under a fluorescence microscope (Axioskop; Zeiss, Oberkochen, Germany) with the stage controller. Location of the AC was determined as the position at which the retinal vessels converged. The numbers of labeled RGCs were counted in the area of $250 \times 250 \mu \mathrm{m}$ centered at the AC at a magnification of $400 \times$. The ratios of RGC densities in the left retinas to those in paired right retinas were obtained to estimate the survival rate of axotomized RGCs.

Intracellular injections of Lucifer yellow. To identify each cell type of surviving RGCs, intracellular injections of Lucifer yellow (LY) were done as described previously (Watanabe et al., 2001). After $7 \mathrm{~d}$ of survival, the retina was dissected and affixed on a layer of $30 \%$ gelatin in the chamber with circulating aerated Ames' medium (A-1420, Sigma, St. Louis, MO). Under a $40 \times$ water immersion objective (5237670; Zeiss) each RGC prelabeled with DiI was penetrated with a microelectrode containing $2 \%$ (w/v) LY carbohydrazide (L0259; Sigma) in $50 \mathrm{~mm}$ Tris buffer, $\mathrm{pH}=7.4$, then LY was injected by applying 5-10 nA negative current. Three regions of the temporal retina, $4-8 \mathrm{~mm}$ of eccentricity, were examined in both left operated and right intact retinas.

Estimation of survival rates of axotomized $\alpha, \beta$, and total cells. The survival rates of axotomized $\alpha$ and $\beta$ cells were estimated by the same method as that described previously (Watanabe et al., 2001). In brief, the ratios of the number of surviving $\alpha$ and $\beta$ cells to those in intact retina $\left(R_{\mathrm{a}}\right.$ and $R_{\mathrm{b}}$, respectively) are given as follows: $R_{\mathrm{a}}=R_{\mathrm{t}} \times P_{\mathrm{al}} / P_{\mathrm{ar}}, R_{\mathrm{b}}=R_{\mathrm{t}} \times$ $P_{\mathrm{bl}} / P_{\mathrm{br}}$, where $R_{\mathrm{t}}$ is the ratio of cell density in the left central retina versus that in the right retina; $P_{\mathrm{al}}$ and $P_{\mathrm{bl}}$ are the proportion of $\alpha$ and $\beta$ cells in the left retina; and $P_{\mathrm{ar}}$ and $P_{\mathrm{br}}$ are those in the paired intact right retina.

We applied another method to estimate the survival of axotomized $\alpha$ cells because the sampled number of $\alpha$ cells in any given retinal area is much lower than that of $\beta$ cells (Fukuda and Stone, 1974; Stone, 1978; Hughes, 1981). We estimated the survival rate of axotomized $\alpha$ cells based on their identification by having a large soma and thick primary dendrites among DiI-labeled RGCs for every $500 \times 500 \mu \mathrm{m}$ area by a step of $1 \mathrm{~mm}$ from the AC throughout the retina. The density counting was not performed at the AC, because the identification of $\alpha$ cells was difficult there based solely on retrograde labeling with DiI. With our estimation, 


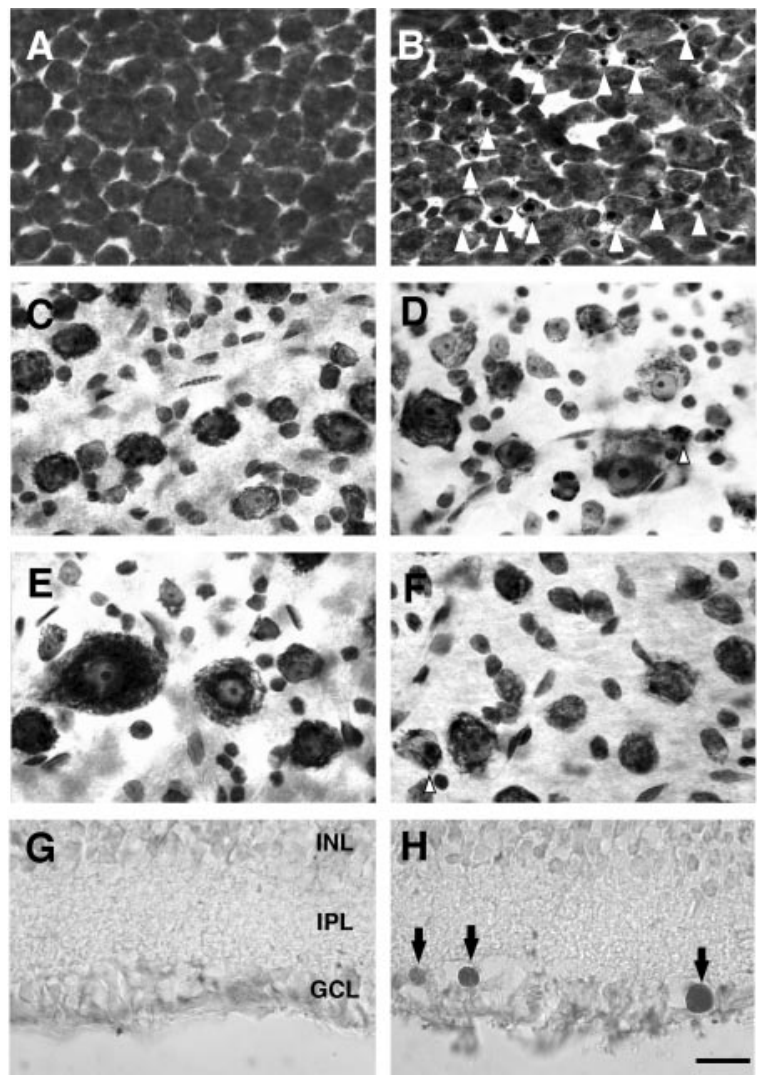

Figure 1. Photomicrographs of Nissl-stained $(A-F)$ and TUNEL-stained $(G, H)$ cat retinas. $A$, $C, E, G$, Intact retinas. $B, D, F, H, O$ ptic nerve-transected retinas $6 \mathrm{~d}$ after optic nerve transection. $A, B, A C$. C, D, Temporal $3 \mathrm{~mm}$ from the $\mathrm{AC}$ on the horizontal line. $E$, $F$, Midpoint between the optic disk and $A C$ (Fig. 2A). Arrowheads indicate pyknotic cells with nuclear chromatin condensation $(B, D, F)$. Note that in $D$, $F$, the occurrence of pyknotic cells was less frequent. $G, H$, Vertical sections from the AC. Arrows in $H$ indicate TUNEL-positive cells. Scale bar, $20 \mu \mathrm{m}$.

the total number of $\alpha$ cells was $5292 \pm 694(n=9$; values are means \pm SD throughout) in intact retinas, corresponding to $\sim 4 \%$ of the total number of DiI-labeled RGCs $(139,704 \pm 8819 ; n=3)$. This value is consistent with the proportion of $\alpha$ cells in cat RGCs reported previously (Fukuda and Stone, 1974; Hughes, 1981).

\section{Results}

Spatiotemporal occurrences of pyknotic cells after optic nerve transection

As shown in Figure 1, many pyknotic cells appeared in the AC $6 \mathrm{~d}$ after optic nerve transection (Fig. $1 B$ ). In contrast, in other retinal sampling areas (nasal and temporal retinal area) fewer pyknotic cells appeared (Fig. 1D,F). Thus, the appearance of pyknotic cells was quite different among the retinal areas sampled. Furthermore, we confirmed the apoptotic death of axotomized RGCs using the TUNEL method in one adult cat on day 6. In intact retina no TUNEL-positive cell was detected (Fig. 1G). In axotomized retina, TUNEL-positive cells were observed sporadically in the GCL. Their nuclei were intensely labeled (Fig. $1 H$ ). In the section of Figure $1 H, 19$ TUNEL-positive cells were detected, whereas fewer than two TUNEL-positive cells per section were detected in the peripheral retina (data not shown). Although we consistently observed that TUNEL-positive cells appeared more frequently in the AC than in the peripheral retina, it was difficult to analyze the occurrence of TUNEL-positive cells quantitatively in vertical sections of the axotomized retina.

We then evaluated the proportion of pyknotic cells in each sampling area (Fig. $2 \mathrm{~A}$ ) to perform quantitative analysis on the

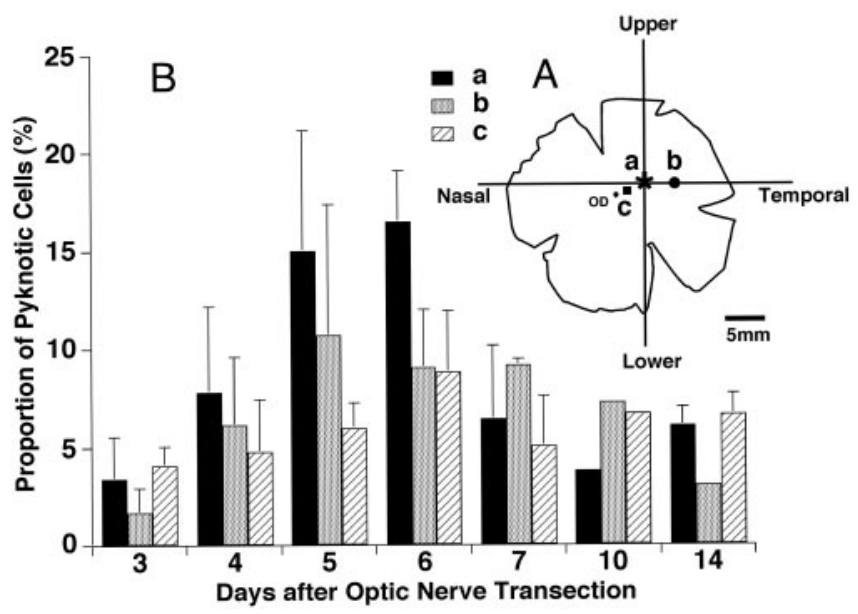

Figure 2. A, Schematic diagram of whole-mounted left retina to show approximate sites of three sampled areas for examinations of the appearance of pyknotic cells after left optic nerve transection. $a$ (asterisk) indicates the $A C, b$ (circle) the site temporal $3 \mathrm{~mm}$ from the $A C$ on the horizontal line, and c (square) the midpoint between the OD (optic disk) and AC. B, Relative proportions of axotomy-induced pyknotic cells in Nissl-stained retinas between days 3 and 14 after optic nerve transection. The data are compared among the three retinal sites examined $(a-c)$. The proportions of pyknotic cells obtained from $1-4$ retinas are shown on ordinates as the means $\pm S D$. The numbers of retinas of three areas ( $A C$, temporal $3 \mathrm{~mm}$, and midpoint) for each operated day were $3,2,2$ (day 3); 4, 4, 4 (day 4); 3, 3, 2 (day 5); 3, 3, 2 (day 6); 3, 3, 2 (day 7); 1, 1, 1(day 10); and 2, 1,2 (day 14).

occurrence of pyknotic cells (Fig. 2B). The proportion of pyknotic cells was highest in the sample from the AC, especially from day 4 to day 6 after optic nerve transection. In Figure $2 B$, the proportions of pyknotic cells are plotted on each survival time after optic nerve transection. The pyknotic cells started to appear on day 3 after optic nerve transection and the proportion of pyknotic cells in all sampling areas gradually increased from day 4 and peaked at approximately day 5 to 6 . Above all, the proportion of pyknotic cells sampled from the AC sharply increased and was highest among the three sampled areas on days 5-7 and sharply declined on days 7-10 after optic nerve transection (Fig. $2 B$ ). This tendency was similar to the proportion of pyknotic cells in relation to neurons of intact retina (data not shown). In contrast, this tendency was less clear in the samples from other retinal areas (Fig. 2B).

In the evaluation of the proportion of pyknotic cells in Nisslstained retinal preparations, we divided the number of pyknotic cells by the total number of Nissl-stained cells, which consisted of both RGCs and displaced amacrine cells, in each retinal region. Therefore, the proportion of pyknotic cells does not represent a real proportion of pyknotic RGCs. In spite of this certain inaccuracy, the data presented in Figure 2 do reflect the real occurrence of pyknotic RGCs because the number of displaced amacrine cells, which were inevitably counted in Nissl-stained preparations, should not be affected after the optic nerve transection (Wong and Hughes, 1987).

\section{Survival-promoting effect of caspase 3 inhibitor on axotomized RGCs}

In the $\mathrm{AC}$ of intact cat retinas, homogenous round somata of RGCs were densely distributed in retrogradely labeled retinas (Fig. 3A). On day 7 , in the optic nerve-transected retinas the number of DiI-labeled RGCs decreased compared with that of intact retina, and DiI particles, which were deposits from dying RGCs, were observed (Fig. 3B). On the other hand, in z-DEVDcmk-injected retinas, DiI-labeled RGCs apparently increased and 

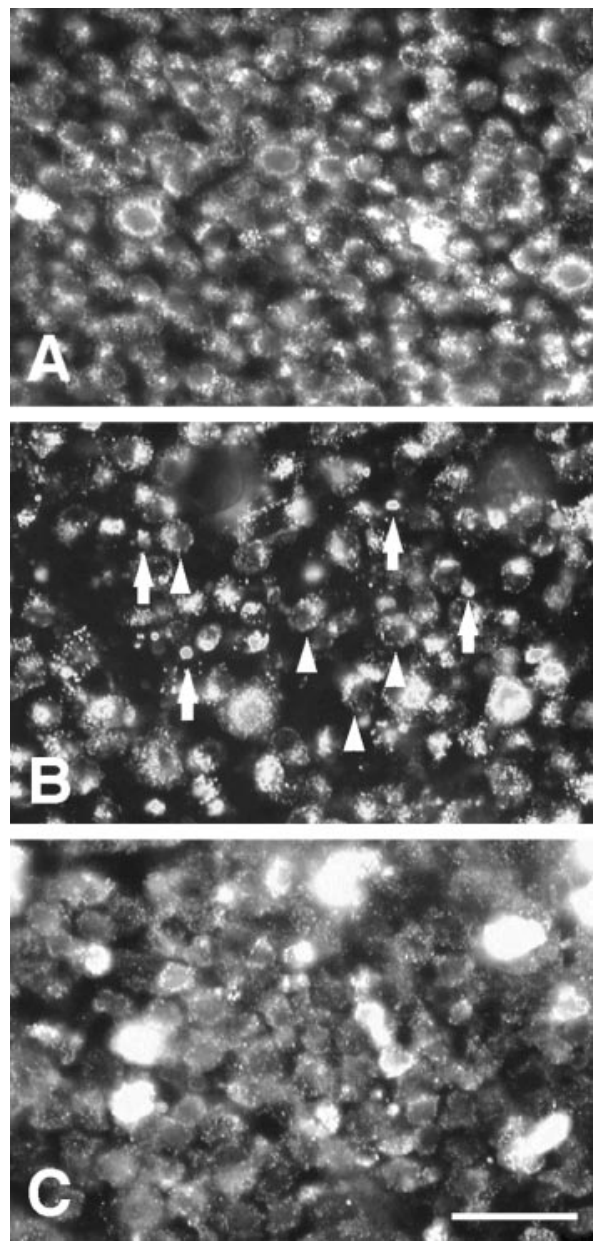

Figure 3. Photomicrographs of Dil-labeled RGCs in the AC. A, Intact retina. $B$, Optic nervetransected retina $7 \mathrm{~d}$ after the surgery. $C$, Optic nerve-transected retina with intraocularly applied z-DEVD-cmk $7 \mathrm{~d}$ after the surgery and treatment. $\ln B$, arrowheads indicate Dil-labeled RGCs and arrows indicate Dil particles. Scale bar, $50 \mu \mathrm{m}$.

a few DiI particles appeared (Fig. 3C). Somata of the surviving RGCs were slightly enlarged after the injection of z-DEVD-cmk.

We evaluated the survival-promoting effects of $z$-DEVD-cmk on axotomized RGCs by calculating the ratios of RGC densities in the operated left retinas versus those of intact right retinas. Figure $4 A$ indicates the survival rates of axotomized RGC on day 7 after optic nerve transection in the AC. In the axotomized retina $7 \mathrm{~d}$ after optic nerve transection without $\mathrm{z}$-DEVD-cmk injection, the survival rates of axotomized RGCs were $44.3 \pm 7.3 \%(n=4)$. Injections of the vehicle (PBS $50 \mu$ l containing 10\% DMSO) did not enhance the survival rates of axotomized RGCs, $51.9 \pm 5.1$ $(n=5)$. However, there was a slight tendency toward increase in the survival rates with vehicle injection, as reported previously in both rats and cats (Mansour-Robaey et al., 1994; RusselakisCarneiro et al., 1996). This effect may be attributable to the inflammation and/or release of some trophic factors subsequent to ocular injury. On the other hand, a single injection of $500 \mu \mathrm{g}$ of z-DEVD-cmk just after optic nerve transection led to a significant increase in survival rates of axotomized RGCs: $75.2 \pm 7.3 \%(n=$ $5 ; p<0.01$ ) (Fig. 4A). It was certain that in the AC of lesioned retina, intravitreal injections of caspase 3 inhibitor promoted the survival of axotomized cat RGCs on day 7 after optic nerve transection.
A

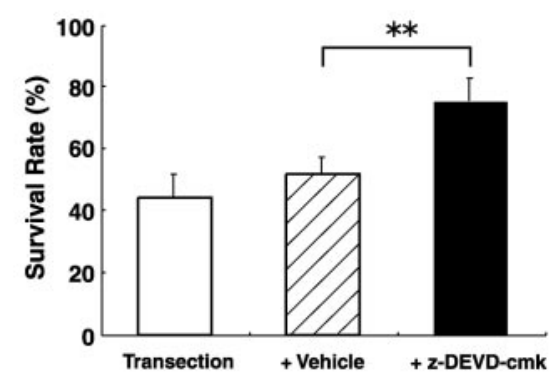

B

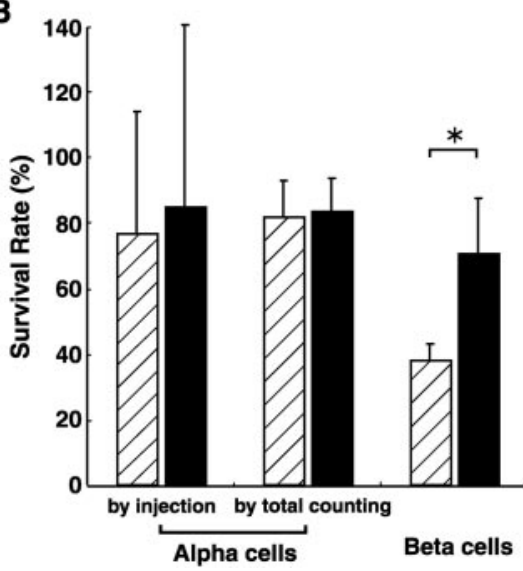

Figure 4. A, Survival-promoting effect of z-DEVD-cmk on the axotomized cat RGCS $7 \mathrm{~d}$ after optic nerve transection. Vehicle injection was of $50 \mu \mathrm{lPBS}$ containing $10 \%$ DMSO. Note that the survival rate significantly increased after z-DEVD-cmk treatment. ${ }^{* *} p<0.01$; unpaired $t$ test. $B$, Cell-type specific survival-promoting effect of z-DEVD-cmk. The RGC survival was studied $7 \mathrm{~d}$ after optic nerve transection and compared between vehicle (striped column) and z-DEVD-cmk injections (black column). The survival rate of axotomized $\alpha$ cells were estimated by two different methods: intracellular injection of $L Y$ and total cell counting by retrograde labeling. A significant survival-promoting effect was obtained only for $\beta$ cells. ${ }^{*} p<0.05$, unpaired and paired $t$ test.

\section{Different effects of caspase 3 inhibitor between axotomized $\alpha$} and $\boldsymbol{\beta}$ cells

Next, we examined the survival rate of each cell type with the injection of $z$-DEVD-cmk or vehicle. Figure $4 B$ indicates the survival rates of axotomized $\alpha$ and $\beta$ cells on day 7 after optic nerve transection. With the estimation of axotomized $\alpha$-cell survival by the intracellular injection of LY, the injection of z-DEVD-cmk did not significantly increase the mean survival rate of axotomized $\alpha$ cells: vehicle injection, $76.5 \pm 37.6 \%(n=3)$ versus z-DEVD-cmk injection, $85.0 \pm 55.3 \%(n=3)$. However, the survival rates of $\alpha$ cells obtained by the intracellular injection of LY varied widely with each sampled retina because of the paucity of sampled $\alpha$ cells. Then we did the total counting of $\alpha$ cells based on retrograde labeling. Here again, the survival rates of axotomized $\alpha$ cells did not increase significantly after the injection of Z-DEVD-cmk [vehicle injection, $81.5 \pm 11.4 \%(n=5)$ versus z-DEVD-cmk injection, $83.5 \pm 9.9 \%(n=4)]$. Thus, we concluded that the injection of z-DEVD-cmk did not enhance the survival of axotomized $\alpha$ cells. In contrast to $\alpha$ cells, the injection of $\mathrm{z}$-DEVD-cmk significantly enhanced the survival of axotomized $\beta$ cells $[70.7 \pm 17.0 \%(n=3 ; p<0.05)$, an $\sim 1.8$-fold increase from the control survival rate of $37.7 \pm 5.4 \%(n=3)]$.

\section{Discussion}

In the present study, we tested the possibility that the rapid death of axotomized $\beta$ cells after optic nerve transection is attributable 
to apoptosis. We obtained three findings in support of the hypothesis. First, after optic nerve transection pyknotic cells preferentially appeared in the $\mathrm{AC}$, in which $\beta$ cells are heavily distributed. Apoptotic nuclear changes of axotomized RGC in the AC were also confirmed with the TUNEL method. Secondly, the proportion of pyknotic cells in the AC sharply increased from day 4 after optic nerve transection, reached its peak on day 6 , and decreased after day 7 , corresponding well with the rapid death period of $\beta$ cells after the optic nerve transection (Watanabe et al., 2001). Thirdly, after the intravitreal injection of caspase 3 inhibitor, the survival of $\beta$ cells on day 7 was specifically increased with apparently no such effect on the survival of $\alpha$ cells.

According to our previous study (Watanabe et al., 2001) the time course of inclination of survival was quite different between the two cell types of cat RGCs within 2 weeks after optic nerve transection; axotomized $\beta$ cells have two regression lines, one sharp decline from day 3 to day 7 (early phase) and the other a gradual decline after day 7 (late phase). In contrast with $\beta$ cells, $\alpha$ cells reveal only a gradual decline in the survival time course through day 14 , with an inclination very similar to that of $\beta$-cell survival after day 7 (Watanabe et al., 2001). Thus, it is quite possible that a common nonapoptotic death mechanism takes place in two major cell types of cat RGCs.

In recent years, the caspase-independent cell death with necrotic-like morphology in vitro has been reported (for review, see Vercammen et al., 1998; Kitanaka and Kuchino, 1999). For example, although Bax-induced caspase activation and apoptotic cell death is blocked by broad-spectrum caspase inhibitor, cell death with necrotic-like morphological change newly progressed with the human leukemic cell line Jurkat (Xiang et al., 1996). As another example, in $b c l$-2 overexpressed mice, one-third of RGCs still die 3 months after optic nerve transection, probably because of the nonapoptotic cell death pathway, which is not inhibited by $b c l-2$ overexpression (Cenni et al., 1996). These findings clearly demonstrate the possibility of a nonapoptotic death mechanism of RGCs after optic nerve transection.

The present study suggests that two major cell types of cat RGCs, $\alpha$ and $\beta$ cells, have a quite different vulnerability to apoptotic death after optic nerve transection. In particular, axotomized $\beta$ cells rapidly suffer from cell death in early phase, and this rapid death is attributed to apoptosis dependent on caspase 3. Thus, the apoptotic cell death after optic nerve transection was cell-type specific among RGC types in adult cats. In addition, the present study directly supported the presumption in our previous study that different mechanisms may underlie the cell death of each RGC type after axotomy in adult cats (Watanabe et al., 2001). Because $\beta$ cells have an important visual function for acute vision or shape recognition among the cell types of cat RGCs (Shapley and Perry, 1986), it is important to find the specific method for the treatment to rescue $\beta$ cells that are vulnerable to optic nerve injury or optic nerve diseases. In addition to the application of caspase inhibitor, which we established in the present study, the neurotrophic factors with forskolin are also shown to rescue $\beta$ cells (Watanabe et al., 2003). Besides these survivalpromoting factors, MK801, an NMDA-glutamate receptor antagonist, was reported to enhance the survival of axotomized cat RGCs (Russelakis-Carneiro et al., 1996). Furthermore, investigators have already started clinical trials of glutamate receptor antagonists to various CNS diseases (Palmer et al., 1999; Haberny et al., 2002). Additional efforts should be made to rescue especially $\beta$ cells for the recovery of acute and higher visual function after optic nerve injury or optic nerve diseases. On the other hand, the finding that $\beta$ cells but not $\alpha$ cells of the cat RGCs suffer from apoptotic cell death after axonal injury may provide an intriguing cue for basic research on molecular mechanisms of parallel processing in the mammalian central visual system, including humans.

\section{References}

Berkelaar M, Clarke DB, Wang YC, Bray GM, Aguayo AJ (1994) Axotomy results in delayed death and apoptosis of retinal ganglion cells in adult rats. J Neurosci 14:4368-4374

Bourteele S, Hausser A, Döppler H, Horn-Müller J, Röpke C, Schwarzmann G, Pfizenmaier K, Müller G (1998) Tumor necrosis factor induces ceramide oscillations and negatively controls sphingolipid synthases by caspases in apoptotic Kym-1 cells. J Biol Chem 273:31245-31251.

Cenni MC, Bonfanti L, Martinou J-C, Ratto GM, Strettoi E, Maffei L (1996) Long-term survival of retinal ganglion cells following optic nerve section in adult $b c l-2$ transgenic mice. Eur J Neurosci 8:1735-1745.

Chaudhary P, Ahmed F, Quebada P, Sharma SC (1999) Caspase inhibitors block the retinal ganglion cell death following optic nerve transection. Mol Brain Res 67:36-45.

Cottee LJ, FitzGibbon T, Westland K, Burke W (1991) Long survival of retinal ganglion cells in the cat after selective crush of the optic nerve. Eur J Neurosci 3:1245-1254.

Fukuda Y, Stone J (1974) Retinal distribution and central projections of Y-, $\mathrm{X}-$, and W-cells of the cat's retina. J Neurophysiol 37:749-772.

Garcia-Valenzuela E, Gorczyca W, Darzynkiewicz Z, Sharma SC (1994) Apoptosis in adult retinal ganglion cells after axotomy. J Neurobiol 25:431-438.

Haberny KA, Paule MG, Scallet AC, Sistare FD, Lester DS, Hanig JP, Slikker W (2002) Ontogeny of $N$-methyl-D-aspartate (NMDA) receptor system and susceptibility of neurotoxicity. Toxicol Sci 68:9-17.

Holländer H, Bisti S, Maffei L, Hebel R (1984) Electroretinographic responses and retrograde changes of retinal morphology after intracranial optic nerve section: a quantitative analysis in the cat. Exp Brain Res 55:483-493.

Hughes A (1975) A quantitative analysis of the cat retinal ganglion cell topography. J Comp Neurol 163:107-128.

Hughes A (1981) Population magnitudes and distribution of the major modal classes of cat retinal ganglion cell as estimated from HRP filling and a systematic survey of the soma diameter spectra for classical neurones. J Comp Neurol 197:303-339.

Isenmann S, Wahl C, Krajewski S, Reed JC, Bähr M (1997) Up-regulation of Bax protein in degenerating retinal ganglion cells precedes apoptotic cell death after optic nerve lesion in the rat. Eur J Neurosci 9:1763-1772.

Kermer P, Klöcker N, Labes M, Bähr M (1998) Inhibition of CPP32-like proteases rescues axotomized retinal ganglion cells from secondary cell death in vivo. J Neurosci 18:4656-4662.

Kitanaka C, Kuchino Y (1999) Caspase-independent programmed cell death with necrotic morphology. Cell Death Differ 6:508-515.

Macho A, Calzado MA, Jiménez-Reina L, Ceballos E, León J, Muñoz E (1999) Susceptibility of HIV-1-TAT transfected cells to undergo apoptosis: biochemical mechanisms. Oncogene 18:7543-7551.

Mansour-Robaey S, Clarke DB, Wang YC, Bray GM, Aguayo AJ (1994) Effects of ocular injury and administration of brain-derived neurotrophic factor on survival and regrowth of axotomized retina ganglion cells. Proc Natl Acad Sci USA 91:1632-1636.

Miyoshi T, Watanabe M, Sawai H, Rasminsky M, Sugioka M, Ohde H, Fukuda Y (1999) Receptive-field properties of adult cat's retinal ganglion cells with regenerated axons. Exp Brain Res 124:383-390.

Palmer GC, Cregan EF, Bialobok P, Sydserff SG, Hudzik TJ, McCarthy DJ (1999) The low-affinity, use-dependent NMDA receptor antagonist AR-R 15896AR: an update of progress in stroke. Ann NY Acad Sci 890:406-420.

Perry VH, Henderson Z, Linden R (1983) Postnatal changes in retinal ganglion cell and optic axon populations in the pigmented rat. J Comp Neurol 219:356-368.

Russelakis-Carneiro M, Silveira LC, Perry VH (1996) Factors affecting the survival of cat retinal ganglion cells after optic nerve injury. J Neurocytol 25:393-402.

Schäfer R, Karbach D, Hoppe J (1998) Multiple intracellular pathways interfere with the activation of a CPP32-like protease induced by serum deprivation of AKR-2B cells. Exp Cell Res 240:28-39. 
Shapley R, Perry VH (1986) Cat and monkey retinal ganglion cells and their visual functional roles. Trends Neurosci 9:229-235.

Silveira LC, Russelakis-Carneiro M, Perry VH (1994) The ganglion cell response to optic nerve injury in the cat: differential responses revealed by neurofibrillar staining. J Neurocytol 23:75-86.

So K-F, Aguayo AJ (1985) Lengthy regrowth of cut axons from ganglion cells after peripheral nerve transplantation into the retina of adult rats. Brain Res 328:349-354.

Stone J (1978) The number and distribution of ganglion cells in the cat's retina. J Comp Neurol 180:753-772.

Vakkur GJ, Bishop PO (1963) The schematic eye in the cat. Vision Res 3:357-381.

Vercammen D, Brouckaert G, Denecker G, Van de Craen M, Declercq W, Fiers W, Vandenabeele P (1998) Dual signaling of the Fas receptor: Initiation of both apoptotic and necrotic cell death pathways. J Exp Med 188:919-930.

Vidal-Sanz M, Bray GM, Villegas-Pérez MP, Thanos S, Aguayo AJ (1987) Axonal regeneration and synapse formation in the superior colliculus by retinal ganglion cells in the adult rat. J Neurosci 7:2894-2909.

Watanabe M, Sawai H, Fukuda Y (1993) Number, distribution, and mor- phology of retinal ganglion cells with axons regenerated into peripheral nerve graft in adult cats. J Neurosci 13:2105-2117.

Watanabe M, Sawai H, Fukuda Y (1995) Number and dendritic morphology of retinal ganglion cells that survived after axotomy in adult cats. J Neurobiol 27:189-203.

Watanabe M, Inukai N, Fukuda Y (2001) Survival of retinal ganglion cells after transection of the optic nerve in adult cats: a quantitative study within two weeks. Vis Neurosci 18:137-145.

Watanabe M, Tokita Y, Katoh M, Fukuda Y (2003) Intravitreal injections of neurotrophic factors and forskolin enhance survival and axonal regeneration of axotomized beta ganglion cells in cat retina. Neuroscience 116:733-742.

Wong RO, Hughes A (1987) The morphology, number, and distribution of a large population of confirmed displaced amacrine cells in the adult cat retina. J Comp Neurol 255:159-177.

Wyllie AH, Kerr JF, Currie AR (1980) Cell death: the significance of apoptosis. Int Rev Cytol 68:251-306.

Xiang J, Chao DT, Korsmeyer SJ (1996) Bax-induced cell death may not require interleukin $1 \beta$-converting enzyme-like proteases. Proc Natl Acad Sci USA 93:14559-14563. 